УДК 620.92

\title{
АНАЛІЗ МОДЕЛЕЙ ФУНКЦІОНУВАННЯ СЕКТОРУ ЦЕНТРАЛІЗОВАНОГО ТЕПЛОПОСТАЧАННЯ КРАЇН ЄВРОПЕЙСЬКОГО СОЮЗУ. ЧАСТИНА 1
}

\author{
Гелетуха Г.Г., канд. тех. наук, Желєзна Т.А., канд. тех. наук, Баштовий А.І., канд. тех. наук \\ Інститут технічної теплофізики НАН Украӥни, вул. Желябова, 2a, Київ, 03680, Україна
}

Розглянуто поточний стан та перспективи розвитку сектору централізованого теплопостачання в Європі, включаючи використання відновлюваних джерел енергії. Проаналізовано основні моделі функціонування ринку теплової енергії. Показано, що ефективність роботи сектору залежить від ступеня розділення генерації та транспортування теплової енергії, можливості доступу незалежних виробників до тепломереж, існуючих форм власності.
Рассмотрено современное состояние и перспективы развития сектора централизованного теплоснабжения в Европе, включая использование возобновляемых источников энергии. Проанализированы основные модели работы рынка тепловой энергии. Показано, что эффективность сектора зависит от степени разделения генерации и транспортировки тепловой энергии, возможности доступа независимых производителей к теплосетям, существующих форм собственности.
The paper covers state of the art and prospects for the development of district heating in Europe, including the use of renewable energy sources. Basic models of district heating system designs are analyzed. It is shown that efficiency of district heating operation depends on the extent of unbundling of heat generation and transmission, opportunities for third-party access to heat networks, existing types of ownership.

Бібл. 7, табл. 1, рис. 3.

Ключові слова: теплова енергія, централізоване теплопостачання, ринок теплової енергї, відновлювані джерела енергії.

БМ - біомаса;

ВДЕ - відновлювані джерела енергії;

TE - теплова енергія;

\section{Загальна характеристика та перспективи розвитку сектору централізованого теплопостачання в Европі}

В Свропейському Союзі найбільша частка кінцевого енергоспоживання (45 \%) припадає на теплову енергію, що набагато більше, ніж у інших напрямках споживання: електроенергія $20 \%$, транспортний сектор - $26 \%$, неенергетичне використання - 9 \%. Житловий фонд використовує $40 \%$ загального обсягу кінцевої енергії, 3 яких, в свою чергу, 68 \% іде на опалення та 14 \% на гаряче водопостачання.

На сьогодні в Свропі нараховується більше 6000 систем централізованого теплопостачання, які забезпечують 12 \% загальної потреби в тепловій енергії. Послугами ЦТ користуються близько 60 млн. чоловік, і більше 140 млн. чоловік живуть в містах, де існує принаймні одна систе-
ТЕЦ - теплоелектроцентраль;

ТОВ - товариство з обмеженою відповідальністю; ЦТ - централізоване теплопостачання.

ма централізованого теплопостачання. У 2013 році частка населення, що користується послугами ЦТ, перевищила 50 \% у восьми європейських країнах: Ісландія - 92 \%, Латвія - 65 \%, Данія $63 \%$, Литва - 57 \%, Естонія - 62 \%, Польща $53 \%$, Швеція - $52 \%$, Фінляндія - $50 \%$.

Левова частина теплової енергії в системах ЦТ Свропи (73 \%) генерується ТЕЦ та когенераційними установками 3 використанням всіх видів палива, а також за рахунок скидної ТЕ промисловості. Близько 19 \% виробляється котельними з викопних палив, а решта (8 \%) - котельними на біомасі та іншими установками на ВДЕ (рис. 1). Цікаво, що в режимі ТЕЦ виробляється і більша частина теплової енергії з ВДЕ (67 \%). Таким чином, очевидно, що в секторі ЦТ ЄС сумісне виробництво теплової та електричної енергії превалює над окремим виробництвом ТЕ. 


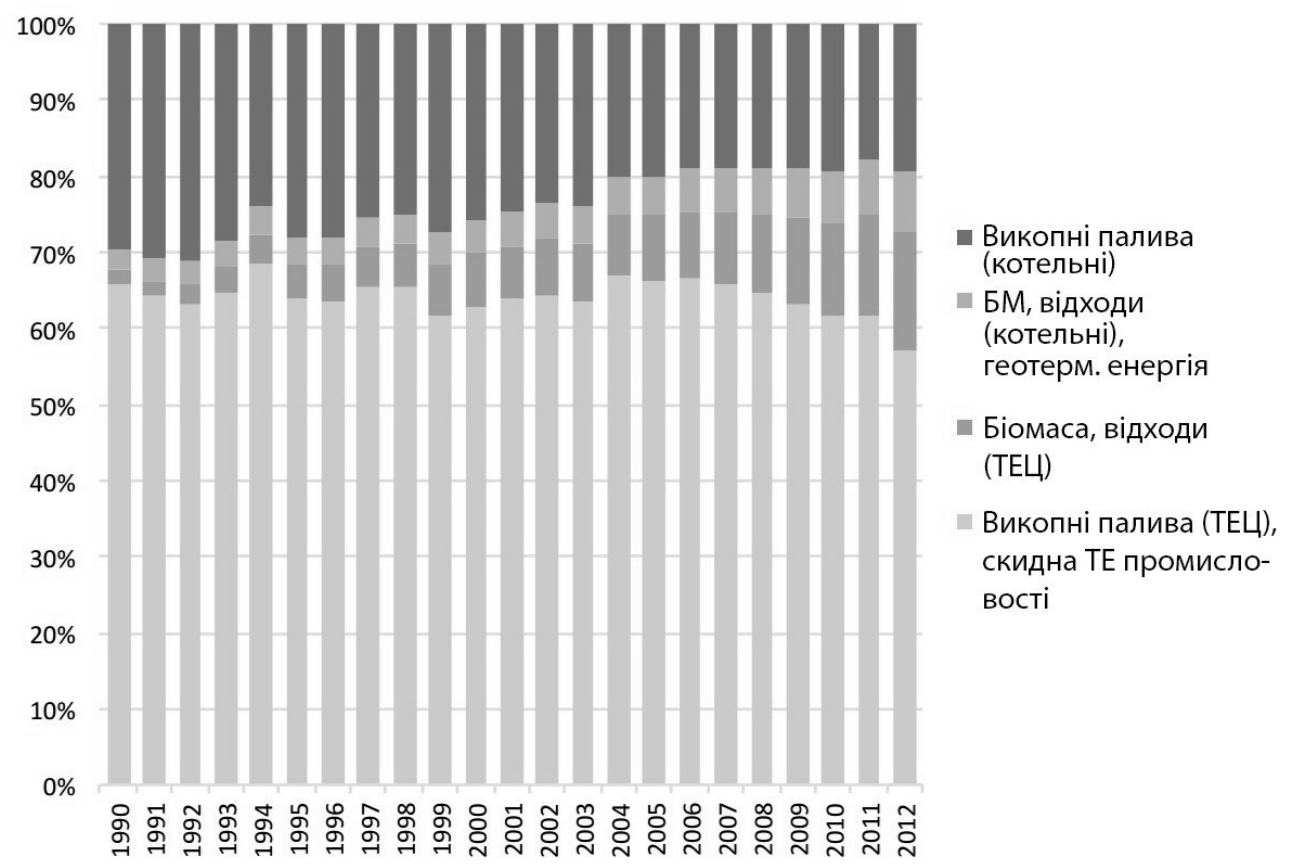

Рис. 1. Зміна структури генерації теплової енергії в секторі ЦТ Євросоюзу [1].

Протягом останніх 20 років має місце стійка тенденція збільшення загальної частки використання відновлюваних джерел в секторі ЦТ, і наразі в середньому по ЄС-28 вона складає більше $23 \%$. Для окремих країн Європи цей по- казник суттєво відрізняється (рис. 2). Лідерами в даному напрямку є Ісландія, Норвегія, Данія, Франція, Швейцарія. У Сербії більше 90 \% теплової енергії у системі централізованого теплопостачання виробляється з викопних палив.

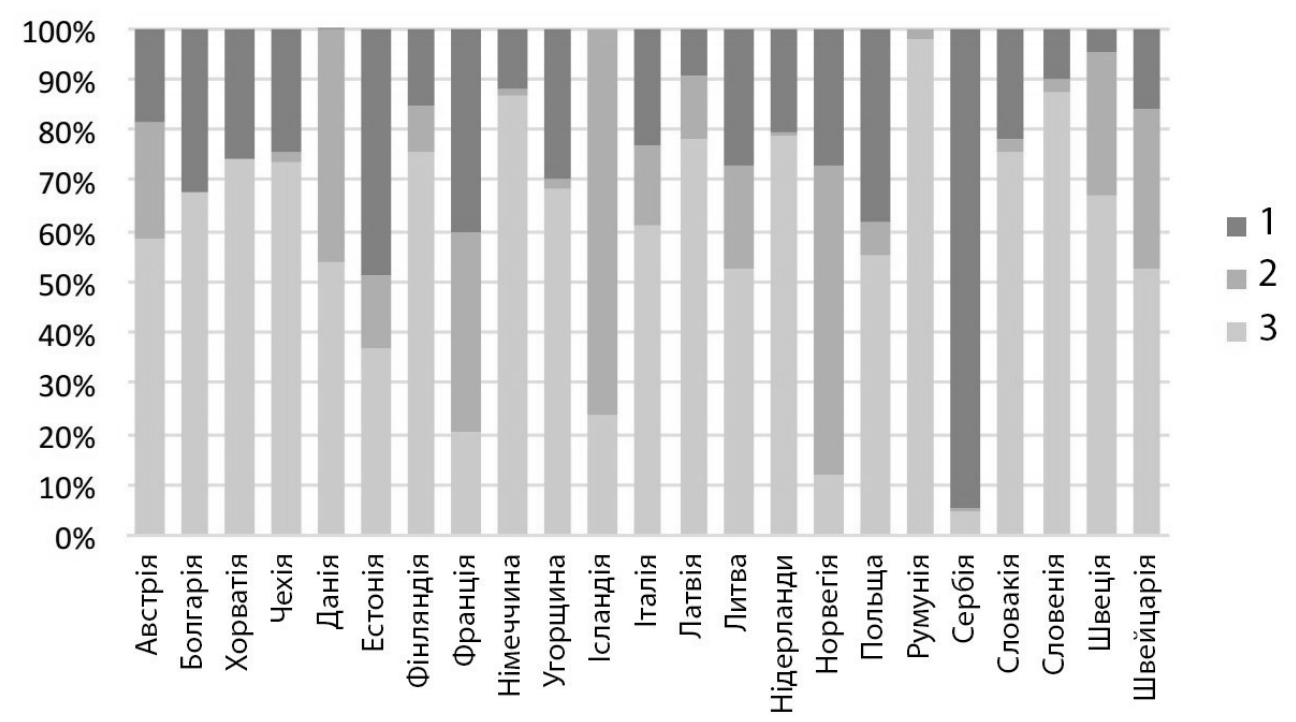

Рис. 2. Структура генерації теплової енергії у секторі ЦТ країн Свропи (2012 р.) [1]:

1 - котельні на викопних паливах, електрокотли та 1/3 TE з теплових насосів;

2 - котельні на біомасі та інші установки на ВДЕ (крім ТЕЦ); 3 - теплова енергія з ТЕЦ та когенерачійних установок на всіх видах палива,

а також скидна ТЕ промисловості та 2/3 TЕ з теплових насосів. 
Важливо зазначити, що згідно Директиви 2012/27/СС «Про енергоефективність» [2], ефективним централізованим теплопостачанням i охолодженням вважається система ЦТ або охолодження, що використовує мінімум 50 \% відновлюваної енергії, 50 \% скидної ТЕ технологічних процесів, 75 \% ТЕ від когенерації або $50 \%$ комбінації цих видів енергії. Також в Директиві 2012/27/СС дається визначення високоефективної когенерації: це когенераційне виробництво, що забезпечує економію первинної енергії на рівні мінімум $10 \%$ порівняно з еталонними значеннями при окремому виробництві теплової та електричної енергії. Виробництво на дрібномасштабних i мікрокогенераційних установах, що забезпечує економію первинної енергії, також може класифікуватися як високоефективна когенерація.

До кінця 2015 р. країни-члени СС повинні були провести комплексну оцінку потенціалу застосування високоефективної когенерації та ефективного ЦТ і охолодження. Якщо ця оцінка виявила потенціал для впровадження відповідних технологій, вигода від яких перевищує витрати, то такі країни мають вжити належних заходів для розвитку інфраструктури ефективного ЦТ i охолодження, високоефективної когенерації та використання ТЕ і холоду, отриманих з ВДЕ та скидного енергопотенціалу технологічних процесів.

\section{Тарифоутворення та існуючі форми власності у секторі централізованого теплопостачання}

Надзвичайно важливими питаннями є регулювання ринку теплової енергії та встановлення тарифів. У країнах Європи наразі існують наступні підходи до встановлення тарифів [3]:

- Тарифи встановлюються теплопостачальними компаніями на конкурентному ринку теплової енергії. Спеціальний уповноважений орган наглядає за ринком теплової енергії на предмет виконання існуючих норм конкурентного права (Швеція, Фінляндія, Данія, Німеччина, Австрія, Бельгія, Франція, Великобританія). Згідно експертної думки, за умов даної моделі ринку TE, ефективна конкуренція між ЦТ та іншими схемами теплопостачання не дає можливості домінуючим постачальникам встановлювати завищені (монопольні) ціни на ТЕ.

- Застосовується спеціальний підхід до встановлення тарифів 3 метою стимулювання ЦТ у порівнянні з іншими схемами теплопостачання, такими як електроопалення (Норвегія) та індивідуальне опалення на природному газі (Нідерланди).

- Максимальні тарифи визначаються згідно встановленої методології і для кожної компанії затверджуються незалежним національним регулятором. При цьому компанія може відступити від встановленого тарифу в сторону його зниження (Естонія, Латвія, Литва, Польща, Чехія, Словаччина, Угорщина, Болгарія, Македонія).

- Тарифи визначаються згідно встановленої методології та затверджуються національним регулятором. Теплопостачальна компанія не може відійти від встановленого ій тарифу (Росія, Білорусь, Румунія, Україна).

Іншими, тісно пов'язаними між собою ключовими проблемами, є анбандлінг у секторі ЦТ та можливість доступу незалежних виробників до теплових мереж. Анбандлінг (від англ. unbundling - розділення) - юридичне розділення існуючих теплопостачальних компаній, принаймні, на дві незалежні компанії. Одна займається виробництвом теплової енергії, а друга - iï транспортуванням та постачанням. Основною метою анбандлінгу є відокремлення виробництва від транспортування, оскільки, як очікується, це сприятиме полегшенню доступу незалежних виробників теплової енергії (в тому числі, з ВДЕ) до існуючих мереж.

Питання підключення незалежних виробників до теплових мереж згідно так званого принципу «доступу третьої сторони» і його вплив на розвиток конкурентного ринку ТЕ наразі активно досліджується та обговорюється в ЄС. Анбандлінг виробництва і транспортування, а також принцип «доступу третьої сторони» вже впроваджені в Євросоюзі на ринках електроенергії та природного газу. Оскільки сектор теплової енергії є набагато складнішім по своїй структурі, питанням власності та особливостям функціонування, проблема широкого застосування моделі «доступу третьої сторони» досі вивчається та аналізується експертами. 
На сьогодні в Європі існують дві базові моделі ринку ЦТ [4]:

- Модель «єдиного покупця», згідно якої постачальник/оператор мережі купує ТЕ у всіх виробників і продає іiі споживачам одного типу на рівних умовах та по однаковій ціні. При цьому у різних ділянок теплової мережі можуть бути різні власники. Функціонування такої моделі можливе, якщо загальна відповідальність за продаж ТЕ кінцевому споживачу лежить на одній компанії, наприклад, операторі теплової мережі. За умов даної моделі вертикально інтегрований оператор тепломережі має надавати стороннім виробникам доступ до мережі на рівних умовах зі своєю власною генеруючою потужністю (рис. 3, a). Модель «єдиного покупця» $\epsilon$ найбільш розповсюдженою у системах ЦТ країн Європи.

- Модель «відкритих теплових мереж», при якій виробник має гарантоване підключення до мережі за умови, що він напряму продає ТЕ своїм власним клієнтам в обсязі необхідного споживання (рис. 3, б). Наразі ця модель застосовується дуже обмежено через іiі складність. Прикладами практичної реалізації $\epsilon$ кілька крупних міст Польщі. Експерти вважають, що модель «відкритих тепломереж» потребує більшого ступеню анбандлінгу системи ЦТ, ніж існує зараз в країнах СC.

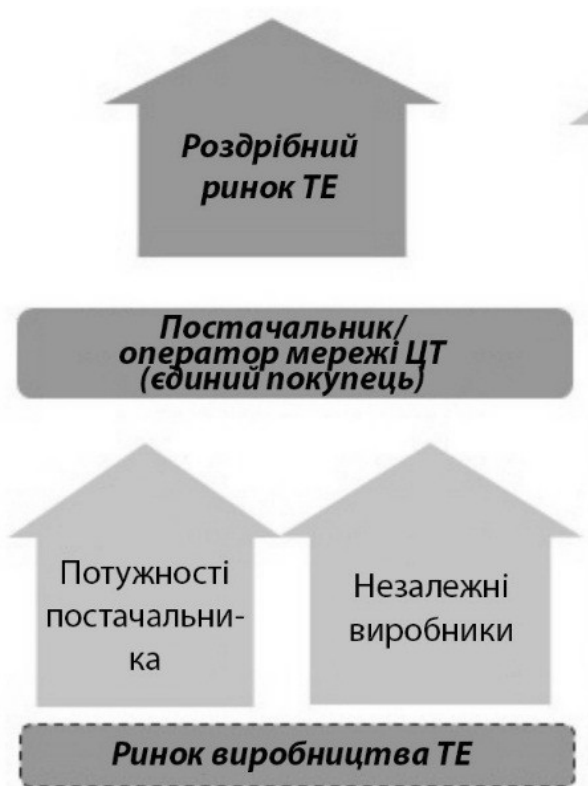

a)

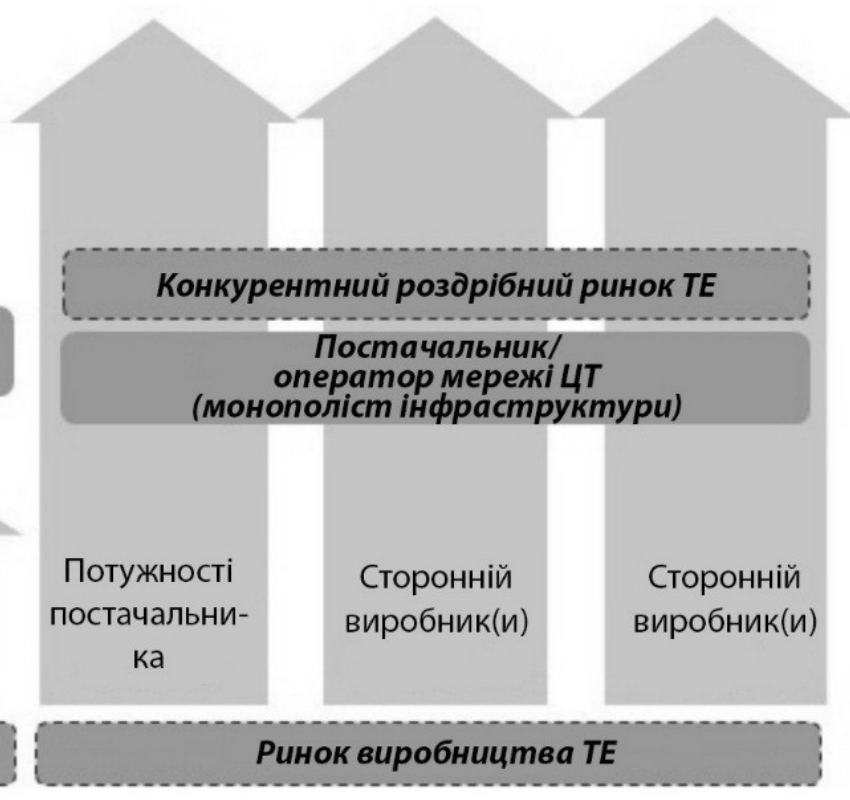

б)

Рис. 3. Базові моделі ринку ЦТ [4]:

а) модель «єдиного покупця", б) модель «відкритих тепломереж».

Можливі наступні схеми реалізації принципу «доступу третьої сторони» до тепломереж при моделі «єдиного покупця» ринку ЦТ [4]:

1. Доступ на договірних умовах (нерегульований доступ).

2. Доступ на частково договірних умовах (частково регульований доступ).

3. Повністю регульований доступ.

При першому підході передбачається, що оператор мережі ЦТ та постачальник самі визначають умови підключення незалежних виробників до теплової мережі. Вони також регулюють порядок та обсяги постачання теплової енергії до мережі від власних генеруючих потужностей та від незалежних виробників. Дана модель впроваджена, наприклад, у Німеччині, Швеції, Фінляндії. Вона спрацьовує, оскільки оператор мережі зацікавлений у підключенні джерела ТЕ з найменшою вартістю.

У другій схемі базові умови доступу до мережі визначено у національному законодавст- 
ві, а деталі, що враховують місцеву ситуацію, можуть бути обговорені та узгоджені між власником тепломережі та незалежним виробником, який хоче підключитися. Можна навести наступні приклади застосування даної моделі:

- У Литві проводяться щомісячні аукціони між незалежними виробниками теплової енергії. При цьому мають виконуватися такі умови, що незалежний виробник не може постачати в мережу більше 1/3 загального теплового навантаження і його вплив на ціну ТЕ для кінцевого споживача не повинний бути дуже сильним.

- У Польщі теплопостачальна компанія зобов'язана купувати теплову енергію з ВДЕ у під’єднаного до місцевої тепломережі виробника в обсягах, що не перевищують потреби споживачів, які обслуговуються даною мережею.

- В Естонії рішення про приєднання незалежних виробників до тепломережі приймається на основі обов'язкового тендеру.

Третя модель передбачає, що умови доступу до теплової мережі повністю визначені у законодавстві або національним регулятором. Якщо незалежний виробник виконав ці вимоги, то власник тепломережі зобов'язаний його підключити. При даному підході важливо, щоб був реалізований анбандлінг, тобто виробництво теплової енергії, принаймні, було юридично відокремлене від транспортування. Практична реалізація моделі з повністю регульованим доступом до тепломережі пов'язана з рядом питань, що потребують ретельного аналізу, зокрема:

- Чи треба продовжувати приєднувати нових виробників до мережі, якщо не очікується ріст загального теплового навантаження системи ЦТ?

- Чи $є$ оптимальним рішенням постачання TE від багатьох малих виробників, якщо одна потужна установка (наприклад, ТЕЦ) може виробити потрібний обсяг і забезпечити при цьому кращі економічні показники?

Згідно доступних даних, модель 3 повністю регульованим доступом до тепломережі майже ніде не реалізована на практиці (за винятком кількох систем ЦТ у великих містах Польщі згідно схеми «відкритих тепломереж», які умовно можна віднести до даної моделі).

Існує стійка експертна думка, що витрати на запровадження повністю або частково регульованого доступу до теплових мереж загалом менші, ніж очікувані економічні та інші вигоди від цього. Механізм приєднання незалежних виробників до тепломереж має бути прозорим, а правила - не дискримінаційними. Це особливо важливо у випадку, коли власник мережі має свої власні генеруючі потужності.

Можна зробити висновок, що ринок теплової енергії має суттєві відмінності у порівнянні 3 ринком електроенергії та природного газу. Питання перспективних напрямків розвитку сектору ЦТ, доцільних механізмів і моделей підвищення його конкурентності та ефективності потребують подальшого аналізу i дослідження.

Ефективність функціонування ринку теплової енергії також залежить від існуючих форм власності та управління. Наразі можна визначити чотири основні форми власності на об'єкти комунальної теплоенергетики [5]:

- повністю державна власність під контролем держави або муніципалітету (Гельсінкі, Мюнхен, Гетеборг, Відень, Будапешт);

- повністю приватна власність (Упсала, Мальме, Норчьопінг, Берлін, Гамбург);

- змішана форма власності та управління державно-приватна;

- неприбуткові кооперативи у комунальній власності (Данія, Австрія, Німеччина).

Перші дві форми - це 100 \% власність держави або приватного капіталу при повній відсутності зобов'язань інших сторін. У категоріях змішаної та комунальної форми власності були розроблені різні моделі, такі як:

1. Договір на експлуатацію або управління (Бурос у Швеціі).

2. Оренда (Таллінн, Вільнюс).

3. Концесія (Париж).

4. Приватизація тільки генеруючих потужностей теплоенергетики (Копенгаген, Варшава, Брно, Рига, Бухарест).

5. Партнерство з міноритарною участю вибраних приватних компаній у статутному капіталі (Пльзень, Дюссельдорф).

6. Партнерство з міноритарною участю при- 
ватного капіталу, залученого на фондовому рин- $\quad$ приватного капіталу (Прага, Братислава). ку (Мангейм, Вроцлав).

8. Повністю приватна власність 3 підтрим-

7. Партнерство 3 мажоритарною участю кою з боку муніципалітету (Саутгемптон).

Табл. 1. Структура форми власності та ключові споживачі у системі ЦТ окремих країн ЄС $[1,5,6]$

\begin{tabular}{|c|c|c|c|c|c|c|}
\hline \multirow[b]{2}{*}{ Країна } & \multicolumn{3}{|c|}{ Виробництво ТЕ } & \multicolumn{3}{|c|}{ Ключові споживачі } \\
\hline & Форма власності & $\begin{array}{c}\text { Кількість } \\
\text { підприємств } \\
\text { чи мереж }(\%) \\
\end{array}$ & $\begin{array}{c}\text { Обсяг ви- } \\
\text { робництва, } \\
\text { ГВт год }\end{array}$ & $\begin{array}{l}\text { Житловий } \\
\text { сектор }\end{array}$ & $\begin{array}{l}\text { Промис- } \\
\text { ловість }\end{array}$ & $\begin{array}{c}\text { Сфера } \\
\text { послуг, } \\
\text { інше }\end{array}$ \\
\hline \multirow{3}{*}{ Швеція } & Муніципальна & $\begin{array}{l}253 \text { мережі } \\
(74 \%)\end{array}$ & $38616(66 \%)$ & \multirow{3}{*}{$59 \%$} & \multirow{3}{*}{$12 \%$} & \multirow{3}{*}{$29 \%$} \\
\hline & Приватна & $\begin{array}{c}66 \text { мереж } \\
(19 \%)\end{array}$ & $15818(27 \%)$ & & & \\
\hline & Державна & $\begin{array}{l}25 \text { мереж } \\
(7 \%)\end{array}$ & $4364(7 \%)$ & & & \\
\hline \multirow{2}{*}{ Данія } & Муніципальна & 55 & $\sim 65 \%$ & \multirow{2}{*}{$64 \%$} & \multirow{2}{*}{$6 \%$} & \multirow{2}{*}{$30 \%$} \\
\hline & Кооперативи споживачів & $\sim 350$ & $\sim 35 \%$ & & & \\
\hline \multirow{3}{*}{ Фінляндія } & Муніципальна & 17 & $11750(39 \%)$ & \multirow{3}{*}{$55 \%$} & \multirow{3}{*}{$10 \%$} & \multirow{3}{*}{$35 \%$} \\
\hline & $\begin{array}{c}\text { Акціонерні компанії у } \\
\text { муніципальній власності }\end{array}$ & 78 & $14067(47 \%)$ & & & \\
\hline & Приватна & 4 & $4197(14 \%)$ & & & \\
\hline \multirow{2}{*}{ Литва } & Муніципальна & $\sim 60 \%$ & - & \multirow{2}{*}{$72 \%$} & \multirow{2}{*}{$7 \%$} & \multirow{2}{*}{$21 \%$} \\
\hline & Орендовані & $\sim 40 \%$ & - & & & \\
\hline \multirow[t]{2}{*}{ Австрія } & Державна (муніципальна) & $90 \%$ & - & \multirow{2}{*}{$37 \%$} & \multirow{2}{*}{$14 \%$} & \multirow{2}{*}{$49 \%$} \\
\hline & Приватна & $10 \%$ & - & & & \\
\hline \multirow{6}{*}{ Польща } & Державна & $14(3 \%)$ & - & \multirow{6}{*}{$70 \%$} & \multirow{6}{*}{$8 \%$} & \multirow{6}{*}{$22 \%$} \\
\hline & $\begin{array}{c}\text { Житлово-будівельні } \\
\text { кооперативи }\end{array}$ & $14(3 \%)$ & - & & & \\
\hline & Муніципальна & $41(9 \%)$ & - & & & \\
\hline & Акціонерні товариства & $118(26 \%)$ & - & & & \\
\hline & TOB & $250(55 \%)$ & - & & & \\
\hline & Інше & $18(4 \%)$ & - & & & \\
\hline Латвія & $\begin{array}{c}\text { Майже всі компанії - } \\
\text { у муніципальній власності. } \\
\text { Приватна власність - } \\
\text { лише в окремих випадках. }\end{array}$ & 68 систем ЦТ & $\begin{array}{c}8 \% \\
\text { (приватні } \\
\text { компанії) }\end{array}$ & $72 \%$ & $2 \%$ & $26 \%$ \\
\hline
\end{tabular}

Ці вісім варіантів містять приклади повної власності держави 3 участю приватного капіталу в управлінні, змішаної власності та повної приватної власності з певними зобов'язаннями 3 боку держави. Тому ця класифікація відображає не тільки форми власності, але й форми управління підприємствами централізованого тепло- постачання. Створюють і інші форми державноприватні партнерства в цілях фінансування, модернізації систем ЦТ та підтримки споживачів.

Аналіз наявних даних свідчить про те, що тенденція до приватизації систем централізованого теплопостачання посилюється як $\mathrm{y}$ західноєвропейських країнах, так і у країнах 
Центральної та Східної Європи. Наразі у різних країнах СС частка приватних форм власності у секторі ЦТ складає до 40 \% (табл. 1).

\section{Висновки}

Аналіз ситуації у секторі централізованого теплопостачання Європи показує, що розвинені країни вже створили конкурентний ринок теплової енергії, а решта країн рухаються в цьому напрямку. Практично у всіх країнах Свросоюзу в більшій чи меншій мірі проведено анбандлінг у секторі теплової енергії та забезпечено умови для доступу незалежних виробників до теплових мереж. Тенденція до приватизації систем централізованого теплопостачання посилюється як у західноєвропейських країнах, так і у країнах Центральної та Східної Європи. Наразі у різних країнах $€$ ч частка приватної форми власності у секторі ЦТ складає до 40 \%.

\section{ЛІТЕРАТУРА}

1. District Heating and Cooling. Country by Country 2015 Survey. Euroheat\&Power.

http://www.euroheat.org/DHC---Statistics-4.aspx?P

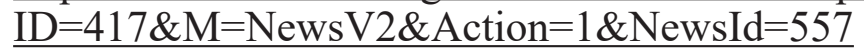

2. Directive 2012/27/EU of the European Parliament and of the Council of 25 October 2012 on energy efficiency http://eur-lex.europa.eu/legal-content/EN/TXT/PDF /?uri=OJ:L:2012:315:FULL\&from=EN

3. Harri-Pekka Korhonen. Overview of DH pricing and regulation in Europe. Fortum, 2012. http://www.1sta.1t/files/events/121204 FORTUM/10 Overview\%20of\%20DH\%20 pricing\%20and $\% 20$ regulation $\% 20$ in $\% 20$ Europe H-P\%20Korhonen.pdf

4. Regulated third-party access in heat markets: how to organize access conditions. Oxera Agenda, June 2014.

http://www.oxera.com/getmedia/195b43b0-6bd34fc4-8b13-df95f80acf2e/Regulated-third-party.pdf. aspx? ext $=. p d f$

5. District Heating System Ownership Guide. DHCAN, 2004

http://projects.bre.co.uk/DHCAN/pdf/ OwnershipManagement.pdf

6. Britt Aronson, Stefan Hellmer. AnInternational Comparison of District Heating Markets, 2009.

http://www.svenskfjarrvarme.se/Global/ FJ\%C3\%84RRSYN/Rapporter\%20och\%20 resultatblad/Rapport $\% 20$ marknad/2009/An $\% 20$ International\%20 Comparison $\% 200 \mathrm{f} \% 20$ District\%20Hetaing\%20Markets.pdf 


\section{ANALYSIS OF OPERATION MODELS IN THE DISTRICT HEATING SECTOR OF EU COUNTRIES. PART 1}

\section{Geletukha G.G., Zheliezna T.A., Bashtovyi A.I.}

Institute of Engineering Thermophysics of the National Academy of Sciences of Ukraine, vul. Zhelyabova, 2a, Kyiv, 03680, Ukraine

The paper covers state of the art and prospects for the development of district heating in Europe, including the use of renewable energy sources. Basic models of district heating system designs and existing ownership types are analyzed. It is shown that single buyer model where the heat supplier/network operator offers heat to similar end customers on equal terms and prices is the most common design of district heating systems across Europe. Efficiency of district heating operation depends on the extent of unbundling of heat generation and transmission, opportunities for third-party access to heat networks and existing types of ownership. It can be observed that many developed European countries have already created the competitive heat market, and the rest of EU countries are on the path to it. Almost all EU countries implemented unbundling in heat market to a greater or lesser extent, and provided network access for third-party heat producers.

References 7, tables 1, figures 3.

Key words: heat, district heating, heat market, renewable energy sources.
1. District Heating and Cooling. Country by Country 2015 Survey. Euroheat\&Power.

http://www.euroheat.org/DHC---Statistics-4.aspx?P $\underline{\mathrm{ID}=417 \& \mathrm{M}=\text { NewsV2\&Action }=1 \& \text { NewsId }=557}$

2. Directive 2012/27/EU of the European Parliament and of the Council of 25 October 2012 on energy efficiency http://eur-lex.europa.eu/legal-content/EN/TXT/PDF /?uri=OJ:L:2012:315:FULL\& from $=\mathrm{EN}$

3. Harri-Pekka Korhonen. Overview of DH pricing and regulation in Europe. Fortum, 2012. http://www.1sta.1t/files/events/121204 FORTUM/10 Overview $\% 20$ of $\% 20 \mathrm{DH} \% 2 \overline{0}$ pricing $\% 20$ and $\% 20$ regulation $\% 20 \mathrm{in} \% 20$ Europe H-P\%20Korhonen.pdf

4. Regulated third-party access in heat markets: how to organize access conditions. Oxera Agenda, June 2014.

http://www.oxera.com/getmedia/195b43b0-6bd34fc4-8b13-df95f80acf2e/Regulated-third-party.pdf. aspx? ext=.pdf

5. District Heating System Ownership Guide. DHCAN, 2004

http://projects.bre.co.uk/DHCAN/pdf/ OwnershipManagement.pdf

6. Britt Aronson, Stefan Hellmer. AnInternational Comparison of District Heating Markets, 2009.

http://www.svenskfjarrvarme.se/Global/ FJ\%C3\%84RRS YN/Rapporter\%20och\%20 resultatblad/Rapport \%20marknad/2009/An\%20

International $\% 20 \mathrm{Comparis}$ on $\% 20$ of $\% 20$ District $\% 20$ Hetaing\%20Markets.pdf

Получено 09.03.2016 Received 09.03.2016 